\title{
ISSUE FOCUS
}

\section{Application of the Law of Self-Determination in a Postcolonial Context: A Guideline}

\section{Ya'kub Aiyub Kadir*}

The development of the law of self-determination has been stagnant in terms of scope and content in its application in the postcolonial context. It requires a new paradigm to persuade the United Nations, its specialized agencies and affiliated organizations to address current phenomenon regarding normative, institutional and community awareness. This research has revealed that the essential meaning of self-determination is a remedial means for an oppressed person both in colonial and postcolonial context. While the colonial context has ended, postcolonial self-determination remains focussed on both repairing the historical wrongs of the colonial context, responding to the breakdown of a state, and recovering from persistent violations against anyone in the State. Accordingly, this paper will contribute to the development of guidelines for these applications: which primarily refer to some degree of internal self-determination (autonomy); and when this proves unsuccessful, external self-determination (independent) can be proposed as the last resort.

\section{Keywords}

Law of Self-Determination, Internal Self-Determination, External SelfDetermination, Postcolonial Context, United Nations ICCPR

\footnotetext{
Lecturer in Law at Syiah Kuala University, Aceh (Indonesia). LL.M.(Oxford Brooks Univ.) The author is indebted for a thoughtful discussion during the class on law of self-determination by Dr. Richard Burchill at the University of Hull. ORCID: http://orcid.org/0000-0002-8765-4263. The author may be contacted at: m.yakub.akadir@unsyiah.ac.id / Address: Law Faculty/Fakultas Hukum, Unsyiah Darussalam, Banda Aceh-Indonesia. 


\section{Introduction}

The discussion on self-determination is of paramount importance in the evolution of human history towards the highest level of society - sovereign Statehood. ${ }^{1}$ It is justified by the criteria of sharing a territory, ${ }^{2}$ which might be formed in the struggle of power and ideas, ${ }^{3}$ progress through self-contemplation and self-identification, along with the ability to declare this status to others. ${ }^{4}$ The concept was originally developed in the modern Europe and the US as the free determination of people for their own political status. ${ }^{5}$

The notion of self-determination was articulated in the context of the era of liberalization of the Europe. Rosas aptly highlighted that it "was for a long time denied or at least belittled as a legal right, bestowed upon a collective entity distinct from the state." Woodrow Wilson in his famous political statement of January 8, 1918 also indicated that the US aimed to secure a "fair and just peace" by employing the "principle of national self-determination."7

The concept was implicitly embedded in Article 22 of the Covenant of the League of Nations of 1919 concerning its Mandates System ${ }^{8}$ leading to the first ever known case on Aaland Island between Finland and Sweden in 1920. Subsequently, it was explicitly included in the UN Charter as the "principle of equal rights and selfdetermination of people" as under Articles 1 and $55^{9}$ and the Non-Self-governing Territories ("NSGT") as under Chapters XI, XII and XIII. ${ }^{10}$ Self-determination was

1 For details on the self-determination between late eighteenth and nineteenth century, see M. Koskenniemi, National Self-determination today: Problems of legal theory and practice, 43 INT'L \& CoMP. L. Q. 241 (1994), available at http://journals.cambridge.org/action/displayAbstract?fromPage $=$ online\&aid=1519068\&fileId=S0020589300056402 (last visited on May 9, 2016).

2 D. Raic, Statehood and the Law of Self-Determination 199-219 (2002).

3 P. Allott, Self-Determination-Absolute Right or Social Poetry, in Modern Law of Self-Determination 177-210 (C. Tomuschat ed., 1993).

4 J. Grant, National Self-Determination and Secession: East Timor, Eritrea, Aceh, and Cabinda in Comparative Context, Paper presented at the 47th annual meeting of the International Studies Association, Mar. 25, 2006, available at $\mathrm{http}: / /$ citation.allacademic.com/meta/p_mla_apa_research_citation/0/9/8/7/9/pages $98794 / \mathrm{p} 98794-1 . p h p$ (last visited on May 9, 2016).

5 V. Lenin, The Right of Nations to Self-Determination 16 (1914; reprinted in 1951).

6 A. Rosas, Internal Self-determination, in Modern LaW and Self-Determination 225 (C. Tomuschat ed., 1993).

7 See Wilson's 'Fourteen Points' speech of January 8, 1918, re-cited from A. de Zayas, A Terrible Revenge: The EthNIC Cleansing of the East European Germans 1944-1950, 14 (1986).

8 M. Nawaz, The Meaning and Range of the Principle of Self-determination, 82 DuKE L. J. 85 (1965), available at http:// scholarship.law.duke.edu/cgi/viewcontent.cgi?article=1957\&context=dlj (last visited on May 9, 2016).

$9 \quad$ Id. at 82.

10 See Trust and Non-Self-Governing Territories (1945-1999), available at http://www.un.org/en/decolonization/ 
inspired by the notion of democracy which was developed through the two World Wars, ${ }^{11}$ following the downfall of four big empires, i.e., Roman, German, AustroHungarian, and Turkish, leading to decolonization across the world. ${ }^{12}$

Under the UN Charter, self-determination is a fundamental ground for achieving universal peace and promoting friendly relations among the nations. Surprisingly, this idea was ignited under colonial rule as a basis for anti-colonial movements. The UN initiated the decolonization project under the Trusteeship Council and the Special Committee for Decolonization (Committee of 24), which was successfully applied in 83 territories, including 72 cases of the NSGT and 11 Trust Territories between 1945 and $1965 .^{13}$ The new self-determination movements after this time $^{14}$ is known as "post-colonial self-determination." ${ }^{, 15}$ In this context, the role of international law and its institutions in developing the law of self-determination have been contentious. ${ }^{16}$ The different circumstances of self-determination claims ${ }^{17}$ have not been followed by justifiable rules, but influenced by a temporary political situation $^{18}$ and the interests of hegemonic powers in maintaining the world order. ${ }^{19}$ It is not surprising that self-determination, although theoretically recognized in many international documents, remains vague in its application. ${ }^{20}$ Musgrave has described this situation in the following manner:

nonselfgov.shtml (last visited on May 9, 2016).

11 A. Cassese, Self-Determination of Peoples, A Legal Reappraisal 321 (1995).

12 R. Emerson, Self-determination, 65 Aм. J. InT'L L. 463 (1971).

13 Committee 24 on decolonisation was established in 1961 by the General Assembly to monitor the implementation of the declaration 1514 (XV) 14 December 1960. See G.A. Res. 1654 (XVI) 3, U.N. Doc. A/4883 (Nov. 27, 1961), available at https://documents-dds-ny.un.org/doc/RESOLUTION/GEN/NR0/167/07/IMG/NR016707.pdf?OpenElement (last visited on May 9, 2016).

14 For details, see M. Weller, Settling Self-determination Conflicts: Recent Development, 20 Eur. J. INT'L L. 111-2 (2009), available at http://www.ejil.org/pdfs/20/1/1788.pdf (last visited on May 9, 2016).

15 For details, see M. Weller, Escaping the Self Determination Trap 144 (2008).

16 J. Crawford, The Right of Self-Determination in International Law: Its Development and Future, in People's Rights 1067 (P. Alston ed., 2001).

17 L. Seshagiri, Democratic disobedience, Reconceiving Self-determination and Secession in International Law, 51 HARV. INT'L. L. J. 553 (2010), available at http://www.harvardilj.org/wp-content/uploads/2010/09/HILJ_51-2_Seshagiri.pdf (last visited on May 9, 2016).

18 In classical international law the question of self-determination was left to the prevailing political power. For details, see supra note 16 , at 11-4.

19 For details on how the US seeks to take a lead in self-determination disputes, see M. HaLPERIN et.al. Self-Determination IN THE New World ORder 48 (1992).

20 K. Senaratne, Internal Self-determination in International Law: A Critical Third-World Perspective, 3 Asian J. INT'L. L. 305-39 (2013), available at http://journals.cambridge.org/action/displayAbstract?fromPage $=$ online\& aid=8971005\&fileId=S2044251313000209 (last visited on May 9, 2016). 
Given the absence of precise guidelines in the international instrument, and also given the existence of widely differing theories of self-determination in political context, the practice of state has become an important means of ascertaining the scope of the right at International Law. ${ }^{21}$

Such ambiguity was also fuelled by the inclusion of self-determination into the two International Human Rights Covenants of 1966, i.e., (a) International Covenant on Civil and Political Rights, and (b) International Covenant on Economic, Social and Cultural Right, which tends to relegate self-determination to be an internal affair of a State. ${ }^{22}$ Consequently, most conflicts over self-determination, which could not be resolved by the internal apparatus of individual States, triggered human rights violations and were considered as threats to international peace and security. Simultaneously, many self-determination movements were considered as preoccupied with territory and resources without consideration of their capacity to exist as a statehood. ${ }^{23}$

The rhetoric of self-determination in international law was not always in line with the practice of self-determination movements on the ground. The former is normative in nature, undefined in terms of scope and content, and characterised by a lack of enforcement mechanisms, while the latter, as a tool for the pursuit of freedom from a government. ${ }^{24}$ A connecting guideline is thus needed.

The primary purpose of this paper is to explore the feasibility of developing such a guideline for the application of self-determination either for autonomy or independence in a postcolonial context. To attain the purpose, the paper is divided into four main parts including Introduction and Conclusion. Part two will define postcolonial self-determination. Part three will shed focus on the development of a guideline for its application.

\section{Postcolonial Self-Determination: Two Approaches}

Two approaches of the UN system for the decolonization program can be traced.

21 T. Musgrave, Self-Determination and National Minorities 91 (1997).

22 Supra note 9.

23 Supra note 11, at 342.

24 Id. at 6. 
The first one is a 'top down' approach, by which the interest of former colonial powers are prevailed in the transferring territory to the chosen regimes in order to maintain their powers even after their independence. ${ }^{25}$ In this case, a colonial power liberalized some of its colonies under the concept of self-determination and at the same time maintained the colonial rule in others without legitimate reasons. ${ }^{26}$ This two-tier policy has then made a negative influence on other movements in the postcolonial era by increasing perception of a 'historical wrong' created by the notion of self-determination as shown at those cases as the division of Pakistan into the west and the east (which became Bangladesh), East Timor, West Papua, and Aceh in Indonesia.

The second one is the justification approach, where the peoples justify their struggle for freedom from colonial powers with self-determination. E.g., the Third World States have been considering their independence as a result of a long and massive struggle, instead of a gift or a transfer of territory under the decolonization project. ${ }^{27}$ The ongoing self-determination movements in the postcolonial context contribute to the overall ambiguity of this principle, ${ }^{28}$ including 'uncertainty' about a justification for intervention, basis for secession, or special arrangements within a State. $^{29}$

A notable example of State secession is the Canadian province of Quebec, which demanded cessation through a referendum in 1995. The Supreme Court of Canada indicated the scenario in which people's rights would include a right to secede, "when a people are oppressed and when a definable group is denied meaningful access to government to pursue their political, economic, social and cultural development. ${ }^{, 30}$ This understanding has conceptualized a remedial character of postcolonial selfdetermination that becomes a domain of human rights law, by which the interest of victims of a group under a State jurisdiction must be taken into account.

25 For details on the establishment of Mandate and Non Self-Governing Territories, see N. Matz, Civilization and the Mandate System under the League of Nations as Origin of Trusteeship, in Max Plank Y.B. U. N. Law 47-95 (2005).

26 E.g., the US opposed self- determination claims inspired by the then Soviet Union, since they were viewed as communist inspired and hence contrary to the US interests. Thus, the US did not support the breakup of Yugoslavia in the initial instance. See supra note 19, at 11.

27 E.g., the Dutch claimed that Indonesia was independent in 1949 at the Round Table Conference in The Hague, whereas Indonesia claimed that it had been independent since August 17, 1945 when Soekarno and Hatta declared independence in Merdeka Palace, Jakarta.

28 Supra note 21, at xi.

29 Supra note 17 , at 38-9.

30 These two questions were addressed by the Supreme Court of Canada in the 1998. See Secession of Quebec (1998) 161 DLR $\left(4^{\text {th }}\right) 385$, re-cited from supra note 21 , at xiii, available at $\mathrm{http} / / / \mathrm{scc}-\mathrm{csc} .1 \mathrm{exum} . \mathrm{com} / \mathrm{scc}-\mathrm{csc} / \mathrm{scc}-\mathrm{csc} / \mathrm{en} / \mathrm{item} / 1643 /$ index.do (last visited on May 9, 2016). 
Equally, the division of external and internal self-determination might not be useful to the colonial and postcolonial context. It may support the argument that for the colonial period self-determination was merely applicable with respect to external meaning, but during the postcolonial era both external and internal selfdetermination can be interchangeably applied. ${ }^{31}$ External self-determination is the right to freedom from hegemony or colonization by other States or empires. Meanwhile, internal self-determination denotes the right of either the people in a country or a minority group of that country for greater autonomy in politics, economy, religion, and culture. ${ }^{32}$ However, this friction would invoke the concept of "internal affair of a State" used mostly by governments to maintain its territory, without due consideration to international customary laws on human rights. ${ }^{33}$ This conceptual shift has brought more controversial interpretations and application. Antonio Cassese described:

Current international law is blind to the demands of ethnic group and national, religious, cultural, or linguistic minorities. Not only does international law refrain from granting any right of internal or external self-determination to these groups, but it also fails to provide any alternatives remedy to the present plight of so many of them. ${ }^{34}$

The meaning of self-determination in the common Article 1 of the two International Human Rights Covenants has transformed an external (independent) into an internal (autonomy) self-determination. ${ }^{35}$ The language of self-determination might have not been clearly interpreted since then. Moreover, the Human Rights Committee's General Comment 12 has excluded self-determination as the right of a people to be enforced. ${ }^{36}$ Rather, it has coped with individual rights as stated in the Covenants. ${ }^{37}$ Nevertheless, there is a limit for external application because it would

31 Cf. supra note 20, at 305-39.

32 Supra note 11, at 64-5.

33 E.g., Moro in Philippines, East Timor, West Papua and Aceh in Indonesia, Bosnia-Herzegovina and Kosovo in former Yugoslavia, and Southern Sudan in Republic of Sudan.

34 Supra note 11 , at $321 \& 328$.

35 C. Fromherz, 'Indigenous People' Courts; Egalitarian Juridical Pluralism, Self-determination, and the United Nations Declaration on the Rights of Indigenous People, 156 U. PA. L. REv. 1358-63 (2008), available at such as the creation of Israeli state over Arab Palestine territory, at https://www.pennlawreview.com/print/old/Fromherz.pdf (last visited on May 9, 2016).

36 See General Comment 12: the Right to Self-determination of Peoples, art. 1, ๆ 1, U.N. Doc. CCPR General Comment 12 (1984), available at http://www.refworld.org/docid/453883f822.html (last visited on May 9, 2016).

37 Supra note 11, at 101-2. 
be subject to the discretion of national and international support.

Consequently, self-determination would have two paradoxical meanings shifting in between internal self-determination providing the people with a degree of autonomy, and external self-determination recognising the peoples' claim to a new State. ${ }^{38}$ This might be relevant questions of postcolonial self-determination under the current international human rights law system. However, it remains unclear in terms of normative standards, institutional arrangements, and international community awareness development. ${ }^{39}$

\section{Developing a Guideline for the Application of Postcolonial Self-Determination}

\section{A. Normative Framework Development}

Self-determination has frequently been referred to in many international legal documents with reference to two major approaches. One is that self-determination is the right of a colonised people to create a State both free from colonial power and in the context of other particular conditions in the postcolonial period. The other is that self-determination is the right of the people to demand autonomy within a State. The first meaning can be observed extensively from the UN Charter, the 1960 Declaration on Decolonisation, the 1970 Declaration on the Principle of International Law concerning Friendly Relations and so forth, while the second meaning can be found in the common Article 1 of the two International Human Rights Covenants. ${ }^{40}$

This formulation was explicitly written as a means to achieve the purposes of the UN Charter for universal peace and friendly relations among nations. ${ }^{41}$ It was then clarified in the colonial context through several repetitive resolutions by the UN General Assembly ${ }^{42}$ and developed into the internal meaning of international human

38 G. Nolte, Succession and External Intervention, in Succession: International Law Perspective 84 (M. Kohen ed., 2006).

39 Supra note 16 , at 10-67.

40 R. Burchill, Self-Determination, in Defining Civil and Political Rights, The Jurisprudence of the United Nations Human Rights Committee 247 (A. Conte \& R. Burchill eds., 2009).

41 U.N. Charter arts. 1 (2) \& 55.

42 E.g., G.A. Res 1514 (XV) 66 A/RES/1514(XV) (Dec. 14, 1960), available at http://www.un.org/ga/search/view_doc. asp?symbol=A/RES/1514(XV); G.A. Res 2625 (XXV) 1970 A/RES/25/2625(XXV) (Oct. 24, 1970), available at http://www.un-documents.net/a25r2625.htm; G.A. Res 2621 (XXV)1 A/RES/2621(XXV) (Oct. 12, 1970), available at https://documents-dds-ny.un.org/doc/RESOLUTION/GEN/NR0/348/86/IMG/NR034886.pdf?OpenElement (all last 
rights law under the common Article 1 (1) of the two Covenants which states that: "All peoples have the right of self-determination. [Emphasis added] By virtue of that right, they freely determine their political status and freely pursue their economic, social and cultural development."

The codification of 'internal meaning' in the Covenants fundamentally upgraded the self-determination principle from a non-binding rule (soft law) to a binding principle (hard law) under international law. As self-determination was finally 'internalized,' its scope, content and application procedures became obscure. The Human Rights Committee ("HRC") has maintained this stance through its General Comment 12 on common Article 1 without specifics as to the meaning of the right by primarily repeating the language of the Covenant text. ${ }^{43}$

Unlike other forms of human rights, self-determination is considered a collective right excluded from the Human Rights Council complaint procedure. ${ }^{44}$ It is intended to place an obligation on a State to protect its people and to improve their economic, social and cultural lives. As this obligation is not monitored by the international legal system, ${ }^{45}$ its enforcement mechanism would largely be determined on a caseby-case basis within State jurisdiction.

Self-determination has something to do with normative obligation of the State to protect its sub-states or marginalized people with a distinct historical, linguistic, religious, ceremonial, institutional structure as well as land ownership within that territory. ${ }^{46}$ There are thus a few cases in which external self-determination might be exercised in the current context. It may occur because of the lack of ability, willingness, or failure of a State to negotiate for the rights of its minority through the internal self-determination mechanisms, particularly in case of grave human rights violation or "crimes against humanity." " The meaning of internal self-determination under the international human rights law would thus be questionable if external selfdetermination is applied without further guidelines and authoritative interpretation. In this regard, restoring a normative framework might be undertaken through the

visited on May 9, 2016).

43 Supra note 37.

44 A. Rosas, The Right of Self-Determination, in Economic, Social and Culture Rights 115 (A. Eide et.al. eds., 2001). See also supra note 40, at 247.

45 Burchill, id, at 247.

46 Article 27 of the International Covenant on Civil and Political Rights provides an important global and specific standard applicable to the Rights of minorities.

47 A. Maguire, Law Protecting Rights; Restoring the Law of Self-determination in the Neo-Colonial World, 12 L. Tex Culture 12-39 (2008), available at http://heinonline.org/HOL/Page?public=false\&handle=hein.journals/ lwtexcu12\&page=12\&collection=journals (last visited on May 9,2016). 
following various ways:

\section{Revising Common Article 1, paragraph 1 of the Covenants}

Article 1 of the Covenants has been a benchmark of the law of self-determination as it has transformed the concept of self-determination from the purposive character of Articles 1 and 55 of the UN Charter into a legal right under international human rights law. This principle of self-determination has also been shifted from merely being a tool of colonised peoples in their pursuit of independence to an understanding of autonomy within a sovereign State.

It is a matter of contention that the language of the common Article 1 to the Covenants is ambiguous. The term, 'all people' can be interpreted in a way that not every single person but to certain people with certain qualifications would have such right to exercise. For internal use, it is subject to negotiation of a people with the central government, while, for external use, it is subject to recognition from both the central government and the international community. Meanwhile, "freely determines political status" might mean that every group of people in the world have the freedom to decide their own political status in terms of an independent statehood. Such an understanding has triggered many self-determination movements anticipating international support. At the same time, they have circumvented the principle of territorial integrity of the State in which they are operating. In this sense, it should be recommended to revise common Article 1 to read: "All people have the right to self-determination. By virtue of that right they may freely negotiate their political status." [Emphasis added] Replacing 'freely determine' with 'freely negotiate' would leave space for conflict resolution internally within the international human rights law system, while the HRC and other international institutions could observe such negotiations for the benefit of the parties involved. ${ }^{48}$

Additionally, the purpose of the self-determination principle should be considered as referring to Articles 1 and 55 of the UN Charter in this revision. In the end, common Article 1 of the Covenants should be amended as follows:

All people have the right to self-determination. By virtue of that right they freely negotiate their political status, economic, social and culture development pursuant to international peace and friendly relations among States. [Emphasis added]

48 J. Crawford, State Practice and International Law in Relation to Unilateral Secession, Report to Government of Canada concerning Unilateral Secession by Quebec, Feb. 19, 1997, available at http://tamilnation.co/selfdetermination/ 97crawford.htm (last visited on May 9, 2016). 
This revision could mitigate the normative conflict between the absolute selfdetermination and the territorial sovereignty of States, harmonizing the purposes of internal and external self-determination.

\section{Defining the Content and Scope of Self-determination}

After analyzing the essential meaning of self-determination under international law, focus can be given on analyzing specific circumstances. The term, "remedial self-determination" ${ }^{49}$ can be employed in terms of repairing and preventing the persistent violation of rights of the people concerned, both for internal and external purposes. The proposed remedial grounds for postcolonial self-determination can be divided into four circumstances.

First, it is 'remedial' in terms of restoring unsettled cases of the UN Trust and NSGT project, such as Palestine, Kurdistan, Western Sahara, Gibraltar, ${ }^{50}$ Tibet, Somaliland, Kashmir, etc. ${ }^{51}$ In these cases, uti possidetis was wrongly applied in the course of decolonization, or an entity was wrongfully incorporated into the newly independent State. ${ }^{52}$ This refers to remedying prior injustice, ${ }^{53}$ which might be widely accepted by the international community. It "has broad support in the legal literature" and "should be acknowledged as part and parcel of positive law." 54 Dickinson, however, argues that the application of remedial self-determination refers to: “... whether injustices capable of generating a right to secede exist; and ... whether the injustices can be resolved without resorting to the ultimate sanction of secession." $" 55$ That is to say that secession is the final option only when internal selfdetermination is considered to have failed.

Second, the remedial solution should be referred to the persisting repressive government against its people. Notable cases include the secession of Bangladesh

49 T. Simon, Remedial Secession: What the Law Should Have Done, from Katanga to Kosovo, 40 GA. J. InT'L. \& Comp. L. 105 (2011), available at https://works.bepress.com/thomas_simon/1 (last visited on May 9, 2016).

50 C. Leathley, Gibraltar's Quest for Self-determination: A Critique of Gibraltar's New Constitution, 9 Or. REv. INT'L. L. 153 (2007), available at http://heinonline.org/HOL/Page?handle=hein.journals/porril9\&div=2\&g_sent= $1 \&$ collection=journals (last visited on May 9, 2016).

51 M. Kohen (ed.), Secession, International Law Perspective 302-15 (2006).

52 Supra note 15 , at 113-4.

53 A. Buchanan, Democracy and Succession, in National Self-Determination and Secession 14 (M. Moore ed., 1998).

54 C. Tomuschat, Secession and Self-determination, in Succession, International Law Perspective 42 (M. Kohen ed., 2006).

55 R. Dickinson, Twenty-First Century Self-determination: Implications of the Kosovo status settlement for Tibet, 26 ARIz. J. INT'L \& COMP. L. 554 (2009), available at http://arizonajournal.org/wp-content/uploads/2015/10/Dickinson.pdf (last visited on May 9, 2016). 
from Pakistan in $1971,{ }^{56}$ Kosovo from Serbia in $2008,{ }^{57}$ and South Sudan from Sudan in $2012 .^{58}$ The international community was seriously concerned with the massive human rights violations in these States, but could not intervene due to the principle of territorial integrity. Local media and NGOs might take a role in disseminating the situation and developing a sustained campaign for this people $e^{59}$ in particular to inform the Human Rights Council under the proposed guideline.

Third, remedy is needed in the event of State collapse such as the breakdown of the Soviet Union and the dissolution of the Federal Republic of Yugoslavia. ${ }^{60}$ It might be less related to international law than the previous cases because these collapses were caused mainly by the domestic institution. However, this manmade disaster is an object of international humanitarian intervention.

Fourth, internal self-determination should be considered. This is a remedy for severely discriminated or imbalanced political and economic power distribution system within a State. A recent example is the special autonomy of Aceh province from the Indonesian government. It was a beneficial solution through a peace agreement of Helsinki 2005 after a long lasting armed conflict between the Aceh Free Movement and Indonesia. ${ }^{61}$

These four divisions can be comprehensively understood as "a remedy for injustice," $" 62$ wherein a group of people in a distinct territory have been effectively denied enforcement of their right to self-determination or autonomy by the ruling governments' persistent violation of peremptory norms. In this sense, the remedial self-determination operated well in the cases of Kosovo and Southern Sudan in the postcolonial context. ${ }^{63}$ As regards the legitimacy of this model of self-determination, Thomas Simon has proposed the assessment of: (1) the relationship between parties, claimant and the parent State; (2) any violation or harmful acts perpetrated by

56 M. Fabry, Recognizing States: International Society and the Establishment of New States since 17765 (2010).

57 Timothy Ash stated: "Kosovo is unique, and there will be more Kosovo." See T. Ash, This Dependent Independence is the Least Worst Solution for Kosovo, GuARDIAN, Feb. 21, 2008, available at http://www.theguardian.com/world/2008/ $\mathrm{feb} / 21 /$ kosovo (last visited on May 9, 2016).

58 See As South Sudan celebrates independence, UN vows support in quest for peace, prosperity, UN News Centre, available at http://www.un.org/apps/news/story.asp?NewsID=38989 (last visited on May 9, 2016).

59 Supra note 4.

60 Former Yugoslavia now became Bosnia-Herzegovina, Croatia, Macedonia, Montenegro, Serbia and Slovenia.

61 M. Aiyub Kadir, Negotiating Aceh Self-determination in Indonesia's Unitary System: A study of Peace Agreement Aceh-Indonesia Helsinki Memorandum of Understanding, 1 ACEH INT'L J. SOc. SCI. 63-76 (2012), available at http:// www.jurnal.unsyiah.ac.id/AIJSS/article/view/1529 (last visited on May 9, 2016).

62 For details on remedial secession, see supra note 49, at 108.

63 Accordance with International Law of the Unilateral Declaration of Independence in respect of Kosovo, Advisory Opinion, 2010 I.C.J. 403, ๆ 84 (July 22), available at http://www.icj-cij.org/docket/files/141/15987.pdf (last visited on May 9, 2016). 
parent States against the seceding territory and its people, such as human rights violation; and (3) whether the claimant has been seriously impacted by the violation of peremptory norms. This assessment module was applied with satisfaction in the Kosovo case, which had a weak relationship with Serbia committing inhuman crimes. ${ }^{64}$ The International Court of Justice ("ICJ") confirmed the legality of the unilateral declaration of Kosovos' independence. ${ }^{65}$ It could be also referred to as an example of the remedial understanding of self-determination in a postcolonial context. ${ }^{66}$

\section{Defining and Demonstrating People's Concern}

Historically, the colonial people were the original beneficiaries of the right of self-determination in the imperialist era. They, however, excluded minority and indigenous peoples in the postcolonial context. Those who were colonised in a distinct territory used to be separated from the colonial power by global distance pushing their efforts to seek the independence. ${ }^{67}$ As the legitimacy of political arrangements depends upon the will of the people in a democratic society, ${ }^{68}$ this would be also a constitutional basis for the people in a defined territory to be liberated from a colonial power. With the end of World War II, colonial powers changed their paradigm following the struggles of colonised peoples for independence and freedom. It became a great momentum for the principle of self-determination to be an international legal principle enforced by many independence declarations in the 1960s of formerly colonised territories. The 1970s witnessed a new kind of declaration such as the Declaration on Principles of International Law concerning Friendly Relations and Cooperation among States ${ }^{69}$ which referred to the selfdetermination of colonised peoples in terms of the UN's decolonisation program. ${ }^{70}$ In the postcolonial context, however, people who might legitimately use the right of self-determination remain questionable as there is no clear definition of 'people' in

64 Supra note 49 , at $172-3$.

65 Supra note 63.

66 Cassese has also distinguished three meanings for self-determination, which can be considered not relevant to current developments. See supra note 11, at 16.

67 I. Young, Two conception of Self-determination, in Human Rights: Concepts, Contest, Contingencies 26 (A. Sarat \& T. Kearns eds., 2001).

68 J. Herbst, Global Change and The Future Of Existing Nation-States, in Self Determination of Peoples, Community, Nation, and State In An InTERdependent World 65 (W. Danspeckgruber ed., 2002).

69 G.A. Res. 2625 (XXV) 28, U.N. Doc. A/8028 (Oct. 24, 1970), available at http://www.un-documents.net/a25r2625. htm (last visited on May 9, 2016).

70 C. Tomuschat, Self-determination a Post-Colonial World, in Modern Law and Self-Determination 225 (C. Tomuschat ed., 1993). 
international law. ${ }^{71}$

Self-determination for indigenous minorities were also developed within the scope of individual concerns under the current international human rights protection system. The UN Declaration on the Rights of Indigenous People 2007 ("UNDRIP") 72 has clearly defined that indigenous self-determination is to be understood as applying to internal self-determination in terms of freedom to express their concerns in politics, economics and culture. ${ }^{73}$ The concept, 'indigenous people' is of great relevance to the circumstances in Australia with its aboriginal people ${ }^{74}$ and in the US with the Native Americans, more than those in the postcolonial world. ${ }^{75}$ The essential issue for indigenous people is "a right over their collective ancestral territories," which is termed as "territorial minorities. ${ }^{76}$ Concerning minorities, meanwhile, Article 27 of the International Covenant of Civil and Political Rights declared:

In those states in which ethnic, religious or linguistic minorities exist, person belonging to such minorities shall not be denied the right, in community with the other members of their group, to enjoy their own culture, to profess and practice their own religion or to use their own language.

Minorities may, therefore, constitute a distinctive ethnic, religious and linguistic group within a territory of a State. It also means discriminatory treatment under these grounds in either centralised or de-centralised territories. The Human Rights Committee's General Comment 23 on Article 27 of the International Covenant on Civil and Political rights has confirmed that the minority right protected by law

71 C. Tomuschat, Secession and Self-determination, in Succession: International Law Perspective 23-6 (M. Kohen, ed., 2006).

72 This declaration was in favour of 143 states, 11 abstained and 4 against it (Canada, Australia, New Zealand and the US). See UN GAOR, 61st session, 107th plenary mtg. Supp No 49, U.N. Doc. A/RES/61/295 (Sept. 13, 2007), available at $\mathrm{http} / / / \mathrm{www} . u n . o r g / \mathrm{depts} / \mathrm{dhl} /$ resguide/resins.htm (last visited on May 9, 2016).

73 Articles 46 of UNDRIP clearly preserved the territorial integrity of independent States and thereby excludes the possibility of secession. See B. Kingsbury, Reconciling Five Competing Conceptual Structure of Indigenous People' Claims in International and Comparative Law, in People's Rights 93-5 (P. Alston ed., 2001).

74 Australia has included self-determination in the statutory bill of rights as an internal self-determination. See D. Lino, The Politic of Inclusion: The Right of Self-determination, Statutory Bills of Rights and Indigenous Peoples, 34 MeLB. U. L. REv. 839 (2010), available at http://law.unimelb.edu.au/_data/assets/pdf_file/0004/1703524/34_3_6.pdf (last visited on May 9, 2016).

75 Indonesia described the indigenous people as an isolated geographically group of people (Masyarakat Hukum Adat). See 1945 Constitution of the Republic of Indonesia, art. 18B (2).

76 J. Castellino \& J. Gilbert, Self-determination, Indigenous People and Minorities, 3 MACQ. L. J. 168 (2003), available at http://www.austlii.edu.au/au/journals/MqLJ/2003/8.html (last visited on May 9, 2016). 
should be the individual rights of members of a minority group ${ }^{77}$ similar to the treatment of indigenous people. General Comment 23 on the right of minorities holds that:

[With] regard to the exercise of the cultural rights protected under article 27, the committee observe that culture manifests itself in many forms, including a particular way of life associated with the use of land resources, especially in the case of indigenous people. That right may include such traditional activities as fishing or hunting and the right to live in reserve protected by law. The enjoyment of those rights may require positive legal measures of protection and measures to ensure the effective participation of members of minority communities in decisions which affect them. ${ }^{78}$

Accordingly, this understanding of internal self-determination in a political sense (paragraph 1) ${ }^{79}$ might address individual concerns within the jurisdiction of a State and the wider notion of minority and indigenous rights. However, it can also stretch to a collective right for a wider degree of autonomy within a State. External self-determination in terms of a collective meaning in line with the "political selfdetermination (paragraph 1)" indigenous people" under the current arrangement. However, the HRC asks States to provide reports on common Article 1 of the International Covenant on Civil and Political Rights and International Covenant on Economic, Social and Culture Rights, under the current human rights mechanism without clarifying whether this applies to an internal or external meaning. Eventually, many States completely ignored Article 1 in their report, as they might be cautious with the emergence of external self-determination. ${ }^{81}$

One might turn towards Anaya's distinction between the constitutive and ongoing aspects of self-determination. Constitutive self-determination means that the political institutions of a State must be built through the participation of the people, as they have a right to "freely determine their political status" in the colonial context, $^{82}$ while on-going self-determination means that "people may live and

77 See The Human Rights Committee, General Comment 23 on Article 27 (Rights of Minorities), U.N. Doc. CCPR/ C/21/Rev.1/Add.5, (Apr. 26, 1994), available at http://tbinternet.ohchr.org/_layouts/treatybodyexternal/Download. aspx?symbolno=CCPR\%2fC\%2f21\%2fRev.1\%2fAdd.5\&Lang=en (last visited on May 9, 2016).

78 Id. $\uparrow 7$.

Supra note 77 , at 170.

Id.

Supra note 77.

S. Anaya, Indigenous People in International Law 104-5 (2004). 
develop freely under the governing institutional order." ${ }^{\prime 3}$ It is then applied as an internal aspect of self-determination for the postcolonial context.

The HRC also distinguishes the application of Article 1 from that of Article 25 (rights to participation), as Article 1 concerns the collective rights of the people to choose their own form of government within a State and Article 25 is concerned with the public affairs of government. ${ }^{84}$ The Committee held that Article 1 can be realized following the participation of all people in public life, which in turn means that the rights identified in Article 25 must be ensured and guaranteed. ${ }^{85}$ This, however, has made more confusion over both internal and external self-determination since Article 27 (right of minorities) clearly applies to the right of individuals belonging to minorities to enjoy a particular culture, including a collective element. ${ }^{86}$ The right of minorities can thus cover the right of indigenous people, but it is rather different from the right of self-determination as a collective right of people within a State to form their autonomous government in any sense.

\section{Procedural Development}

There is a confusion of common Article 1 of the Covenants on whether the complaints procedure should be carried out through an individual or collective channel. Under the Optional Protocol ("OP") 1, the HRC can only receive individual complaints against the States. The Committee's General Comment 12, however, has stressed that self-determination is a collective right, not individual, so that the right under the current arrangement should be unenforceable. In practice, the Committee has rejected the Ominayak case affirming that: "The author, as an individual, could not claim under the OP to be a victim of a violation of the right to self-determination [...] which deals with rights conferred upon peoples as such." ${ }^{87}$ On the one hand, the HRC has invited the States to report on compliance of Article 1, while, on the other hand, it has rejected the complaints brought by the peoples against the States as

83 Id. at 106.

84 General Comment 25, U.N. Doc. CCPR/C/21/Rev.1/Add.7 (Aug. 27, 1996), ๆ 2, available at http://tbinternet.ohchr. org/_layouts/treatybodyexternal/Download.aspx?symbolno=CCPR $\% 2 \mathrm{fC} \% 2 \mathrm{f} 21 \% 2 \mathrm{fRev} .1 \% 2 \mathrm{fAdd} .7 \& \mathrm{Lang}=\mathrm{en}$ (last visited on May 9, 2016).

85 Id.

86 Supra note 77, ๆ 3.2. See also supra note 82.

87 See Bernard Ominayak, Chief of the Lake Lubbock Band v. Canada, Communication No 167/1984, G.A. 45th sess, Supp No 40, U.N. Doc. A/45/40 (Mar. 26, 1990) in ICCPR, Selected Decision of the Human Rights Committee under the Human Rights Protocol, vol. 3, 62 (2002), available at http://www.ohchr.org/Documents/Publications/ SDecisionsVol3en.pdf (last visited on May 9, 2016). 
being incompatible with OP 1 and General Comment $12 .{ }^{88}$ On the violation of Article 1, the Committee has rejected the Mikmaq Tribal Society v. Canada case, since Mikmaq could not claim to be an individual victim in accordance with the OP. ${ }^{89}$

There is no explanation on how 'people' are entitled to claim to the HRC, as Article 1 of the Covenants has still excluded the OP and the Committee's legal positions. In relation to Mikmaq Tribal Society v. Canada, Roger Errera raised a question concerning the ambiguous interpretation of people's qualification to the right of self-determination for both internal and external parameters under the OP. ${ }^{90}$ Thus, a complaint mechanism should be established for the collective right of selfdetermination by revising the OP and General Comment 12 in order to provide a space for self-determination movements to claim statehood under international human rights protection mechanisms.

\section{B. Strengthening Institutional Mechanism Development ${ }^{91}$}

Self-determination had neither effective enforcement measures, nor clear terms after the decolonization process. Both the UN Trusteeship Council and the NSGT settled 11 trust territories ${ }^{92}$ and 16 remaining NSGT $^{93}$ under the Special Committee for decolonization (Committee 24), ${ }^{94}$ respectively. The Trusteeship Council suspended operations on November 1, 1994, ${ }^{95}$ while Committee 24 is still working actively under the third international decade for eradication of colonialism 2011-2020. ${ }^{96}$

88 D. Mcgoldrick, The Human Rights Committee: Its Role in the Development of the ICCPR 255 (1991).

89 The Mikmaq tribal society v. Canada, Communication No. 78/1980, U. N. Doc. Supp. No. 40, A/39/40 (July 29, 1984), in ICCPR, Selected Decision of the Human Rights Committee under the Human Rights Protocol, vol. 2, 23-5 (1990), available at http://www.ohchr.org/Documents/Publications/SelDec_2_en.pdf (last visited on May 9, 2016).

90 This is in line with the individual opinion of Mr. Roger Errera, member of the Human Rights Committee relating to the admissibility of Communication No. 78/1980 (A.D. v. Canada). See id. at appendix (Individual Opinion).

91 Cf. supra note 19, at 112-4.

92 See The United Nations and Decolonization: Trust Territories that have achieved self-determination, available at http://www.un.org/en/decolonization/selfdet.shtml; the complete list of trust and NSGT; http://www.un.org/en/ decolonization/nonselfgov.shtml (last visited on May 9, 2016).

93 The beneficiaries and institutions of self-determination are referred to as non-self-governing territory which is administered by the Trusteeship Council. See U.N. Charter chs. XI \& XII.

94 Committee 24 on decolonisation was established in 1961 by the General Assembly to monitor the implementation of the declaration 1514 (XV) 14 December 1960. See G.A. Res. 1654 (XVI) 3, U.N. Doc. A/4883 (Nov. 27, 1961), available at https://documents-dds-ny.un.org/doc/RESOLUTION/GEN/NR0/167/07/IMG/NR016707. pdf?OpenElement (last visited on May 9, 2016).

95 See the official website of Trusteeship Council, available at http://www.un.org/en/sections/about-un/trusteeshipcouncil/index.html (last visited on May 9, 2016).

96 G.A. Res. 65/119, U.N. Doc. A/65/430 (Dec. 10, 2010), available at http://www.un.org/en/ga/search/view_doc. asp?symbol=A/65/430 (last visited on May 9, 2016). 
The Trusteeship and the NSGT systems were based on the situation of the two World Wars. ${ }^{97}$ It is thus impossible to extend the scope of such institutions as the Trusteeship Council and Committee 24 without amending Article 108 of the UN Charter. ${ }^{98}$ This indicates that the law of self-determination became stagnant by the final settlement of the Trust and NSGT by the Trusteeship Council within the colonial context, while no other agencies have been formally established as bodies for enforcing self-determination laws under the UN system. ${ }^{99}$

Committee 24 has been organized for the remaining NSGTs relevant to the colonial context, instead of self-determination movements. Accordingly, the HRC would be a feasible, legitimate, and valid institution for the settlement of current postcolonial self-determination movements such as those under the Unrepresented Nations and Peoples Organization (“UNPO"). ${ }^{100}$

The UN has been carrying out its decolonization program for NSGT for several decades, but this program has faced several challenges. E.g., Committee 24's recommendations were often disrespected by the hegemonic powers of the UN because it is composed of developing countries, lacking political power under the UN system. They were even biased from the members of Committee 24 as some self-determination movements were going on within their own countries. ${ }^{101}$ They also see their roles as pertaining to the General Assembly resolution 1415 for decolonization, ${ }^{102}$ focusing on the list of 16 NSGT within the colonial context. Eventually, Committee 24 has put aside the self-determination principle under the Covenants for the postcolonial context.

Various claims exist for both internal (autonomy) and external (independence) selfdetermination beyond the colonial context. ${ }^{103}$ Notable examples are the independence claim of Kosovo on February 17, 2008, the independence of South Sudan on July 9,

97 J. Summers, People and International Law: How Nationalism and Self-Determination Shape a Contemporary Law of NATIONS 207-8 (2007).

98 J. Crawford, The Creation of State in International Law 600-1(2006).

99 G. Simpson, The Diffusion of Sovereignty: Self Determination in the Post Colonial Age, 32 Stan. J. InT’L L. 255 (1996), available at $\mathrm{http} / / /$ connection.ebscohost.com/c/articles/27475028/diffusion-sovereignty-self-determination-postcolonial-age (last visited on May 9, 2016).

100 For details, see the official website of Unrepresented Nations and Peoples Organization, available at http://www.unpo. org (last visited on May 9, 2016).

101 The members of the Committee are as follows: Antigua and Barbuda, Bolivia, Chile, China, Congo, Côte d'Ivoire, Cuba, Dominica, Ecuador, Ethiopia, Fiji, Grenada, India, Indonesia, Iran, Iraq, Mali, Nicaragua, Papua New Guinea, Russian Federation, Saint Kitts and Nevis, Saint Lucia, Saint Vincent and the Grenadines, Sierra Leone, Syria, TimorLeste, Tunisia, United Republic of Tanzania and Venezuela.

102 G.A. Res. 1415(XIV) 32, U.N. Doc. A/4138 (Dec. 5, 1959), available at http://www.un.org/documents/ga/res/14/ ares14.htm, (last visited on May 9, 2016).

103 See Stages in the Development of Self-Determination in International Law, in supra note 99. 
2011, the referendum on Crimea in Ukraine, the Scottish independence referendum in the UK, ${ }^{104}$ and Catalonia in Spain, all during 2014. Now is the time to establish new and appropriate institutions in order to respond to such ongoing questions of self-determination. The HRC and the UN Committee on Economic, Social and Cultural Rights, however, has left Article 1 of the Covenant on self-determination uncertain. ${ }^{105}$ These committees reported the policies of a member State to its citizens to the General Assembly, but are not much concerned with the exercise of selfdetermination in practice. It can be observed in the dismissal of the said practice by General Comment 12.

Due to the absence of enforcement mechanism of these rights, self-determination movements in the postcolonial period are managed by the common procedures of the UN regarding maintenance of global peace and security. The Security Council and the General Assembly are authorized to intervene in domestic affairs of a member State when the conflicts are considered to have severely negative influences on human rights violations. Nonetheless, it is undeniable that the Security Council's permanent members, however, are not fully out of this accusation of violation of human rights as clearly shown in cases, e.g., the UK with Scotland, France with Corsica, China with Tibet, and Russia with Crimea. ${ }^{106}$ It would imply that the Security Council might have prevented further developments of the laws of selfdetermination for the postcolonial context. ${ }^{107}$ In some cases, the UN and its organs have been involved in self-determination based conflicts through collective forces or monitoring missions, when humanitarian crises occurred. However, the supports to some self-determination claims would be risky to fuel up the negative impact on the conflicts. $^{108}$

The ICJ has been also playing pivotal role in resolving some thorny legal questions arising on self-determination claims ${ }^{109}$ by adjudication and advisory

104 See, e.g., Z. Oklopcic, Reflections on self-determination, and the status of Kosovo in light of the Report of the Independent International Fact-Finding Mission on the Conflict in Georgia, available at http:/www.ejiltalk.org/reflections-on-selfdetermination-and-the-status-of-kosovo-in-light-of-the-report-of-the-independent-international-fact-finding-missionon-the-conflict-in-georgia (last visited on May 9, 2016).

105 For details on these agencies, see A. Huff, Indigenous Land Rights and the New Self-Determination, 16 CoLo. J. INT'L ENv. L. (2005), available at http://heinonline.org/HOL/Page?handle=hein.journals/colenvlp16\&div=17\&g sent=1\&collection=journals (last visited on May 9, 2016).

106 For details on the US role in self-determination disputes, see supra note 19.

107 For details on the proposal of the Security Council reform on September 2005 World Summit, see N. Schrijver, Reforming The UN Security Council in Pursuance of Collective Security, 12 J. Conflict \& Security L. 127-38 (2007), available at $\mathrm{https}$ ://openaccess.leidenuniv.nl/handle/1887/12562 (last visited on May 9, 2016).

108 V. Kattan, From Coexistence to Conquest: International Law and the Origins of the Arab-Israeli Conflict 18911949 (2009).

109 E.g., it confirmed the people determinant of territory in Western Sahara case and erga omnes character of self- 
opinions. ${ }^{110}$ Noticeable examples are the cases concerning South West Africa (Namibia), ${ }^{111}$ Northern Cameroon, ${ }^{112}$ Western Sahara, ${ }^{113}$ East Timor, ${ }^{114}$ and Kosovo. ${ }^{115}$ The ICJ generally "favoured the solution most consistent with the self-determination of the people concerned and affirmed the validity of the legal principle concerned with a colonial territory."116 Such judicial function, however, has not significantly contributed to the development of an institutional framework for self-determination.

As the current institutional arrangements for the settlement of self-determination conflicts have been considered divergent, sporadic and unsystematic, a new institution would be required to cope up with this in more comprehensive ways. The HRC can be the most likely institution to lead this role for several reasons. First, self-determination has been already stipulated in Article 1 of the two Covenants, especially on the implementation of which the Council has jurisdiction. Second, the Security Council was not found fair and consistent in either supporting some selfdetermination movements or rejecting others. Third, it is difficult to effectively settle postcolonial self-determination movements because the Trusteeship Council was closed in 1994 and Committee 24 is merely working for the 16 remaining NSGTs. For this goal, the OP and General Comment 12 should be revised and the guidelines should be drafted.

The guidelines would propose that the role of the HRC be strengthened: (1) to receive of peoples' self-determination claims; (2) to identify the degree and validity of self-determination claims; (3) to initiate internal negotiations with the existing States concerned; to provide recommendations for the settlement of problems between a people and the State in which they reside; and (4) to actively educate the people concerned on the implications of the process of self-determination on a long term basis. In some cases, finally, the Committee can seek the advisory opinions

determination. See Case concerning East Timor (Port. v. Austl.), Judgement, 1995 I.C.J. 102, ๆ 29 (June 30), available $a t$ http://www.icj-cij.org/docket/index.php?sum=430\&p1=3\&p2=3\&case=84\&p3=5 (last visited on May 9, 2016).

110 I.C.J. Statute arts. 38 (1) \& 65 (1).

111 Legal Consequences for States of the Continued Presence of South Africa in Namibia (South-west Africa) Notwithstanding Security Council Resolution 276, Advisory Opinion, 1971 I.C.J. 78 (June 21), available at http://www.icj-cij.org/docket/ files/53/5597.pdf (last visited on May 9, 2016).

112 Case concerning the Northern Cameroons (Cameroon v. U.K.), Judgement, 1963 I.C.J. 65 (Dec. 2), available at http:// www.icj-cij.org/docket/files/48/5209.pdf (last visited on May 9, 2016).

113 Judge Dillard stated in his separate opinion that: "It is for the people to determine the destiny of the territory and not the territory the destiny of the people.” See Western Sahara, Advisory Opinion, 1975 I.C.J. 12, 122 (Oct. 16), available at http://www.icj-cij.org/docket/files/61/6211.pdf (last visited on May 9, 2016).

114 Supra note 109

115 Supra note 63 , at 92.

116 Supra note 16, at 31-3. See also supra note 97, at 255-60. 
from the ICJ for the settlement of the self-determination movement in question. This Committee would decide which movement has the potential for independent statehood and when its supervision for statehood scheme is required in a transitional period. ${ }^{117}$ Other movements should also be guided in such a way as to achieve an appropriate autonomy from its internal self-determination.

When the initial effort to internally resolve the conflict through negotiations between the people and the State would be prevalent, the Committee should offer the first solution for a degree of autonomy. Otherwise, the persistent repression by a government over its people will be unavoidable. Here, the Committee can, after careful consideration, offer a proposal for remedial self-determination.

\section{Developing Awareness of the International Community}

The UN has tried to end or slow down the growing number of States since the end of the decolonization process. The UN and its organs, however, have failed to provide well-informed education to the international community on the topic of self-determination. As a result, many newly emerged self-determination movements were passionately expectant of a better life by means of achieving statehood. On the other side, there is still a tendency to preserve status quo of national borders after decolonisation. Changing borders can be viewed as 'instability' around the world. The former UN Secretary General U Thant stated: “The United Nations' attitude is unequivocal. As an international organization, the UN has never accepted and does not accept, and I do not believe it will ever accept the principle of secession of a part of its member state." ${ }^{118}$ His remarks relate to the principle of the inviolability of national borders and the goal of non-interference in internal affairs of other States in keeping with the principle of territorial sovereignty. ${ }^{119}$ This principle abstained the UN from intervening in civil wars of self-determination, inter alia, in Nigeria in the late 1960s, Pakistan in 1970s, Indonesia in 1990s, etc. ${ }^{120}$

Many developing countries, however, have not been fully aware of their role in potential settlement of self-determination disputes through human right-based approaches. Such failures have worsened the situation. Tensions have risen to the level of armed conflict or civil war with gross human rights violations. Therefore, the existing distinction between external and internal self-determination might have

\footnotetext{
117 Supra note 63.

118 Supra note 47.

119 Supra note 19 , at xi.

120 Id. at xi.
} 
failed to capture the wide range of challenges and dilemmas that self-determination movements present in the international community. ${ }^{121}$ Eventually, newly independent States have been cautious to report on the implementation of common Article 1 of the two Covenants to the HRC and to protect self-determination movements from international intervention. The question of self-determination movement should be thus fairly disseminated by not only each State, but also the international community as a whole. The HRC must assess the capacity of a group of peoples' self-determination claim to achieve independent statehood clearly. ${ }^{122}$

It should be noted that the emergence of postcolonial self-determination is due to not merely the poor treatment by the State to particular groups of people, but also the misled direction of the decolonisation project and the dissolution of States historically. When a group of people demand self-determination on one side, the State would have been equating it to rebellion and sought to quell it by any means necessary. Grave human rights violation might be caused by the misunderstanding of self-determination and the lack of a democratic means to negotiating peace. ${ }^{123}$ It is thus the role of the HRC to design, inform and discuss a better way for the peoples as well as for the international community in general.

\section{Conclusion}

Since the end of World War II, the right to self-determination has been evolving in international law from territorial and political independence of colonized peoples to the right of autonomy within an independent State for indigenous peoples, minorities and ethnics groups. The postwar decolonization was processed through the UN mechanisms along with the respective colonial powers. This mission was dominated by the power elites of the UN who selected and parcelled out the areas of the colonial world into independent States under the Mandate System of the League of Nations and NSGT System of the UN. This situation might not only support the principle of territorial integrity for the then newly emerging States, but also limit the proliferation of States in the world.

121 Id. at 48.

122 For details on the African Countries' claims, see A. Idowu, Revisiting the Right to Self-Determination in Modern International Law: Implications for African States, 6 Eur. J. Soc. SCI. $43-55$ (2008), available at http://www. europeanjournalofsocialsciences.com/issues/ejss_6_4.html (last visited on May 9, 2016).

123 Supra note 14. 
However, the failure of settling self-determination claims in many States would have threatened international peace and security. This fuels the emergence of a "remedial self-determination," encompassing those four circumstances as: (1) restoration of the historical wrong in the decolonization process; (2) response to the dissolution of the State; (3) freedom from persistently repressive government practices; and (4) provision of a degree of autonomy for certain sub-states. To this end, the development of precise guidelines for these applications is required to cover normative, institutional, and international awareness.

It is eventually argued that the creation of a State is not the only ultimate goal of the people; they further attempt for a better life with peace and security for their future. However, many self-determination movements have been trapped in their longing for statehood, rather than understanding the means to achieve a higher living standard in the future, a goal which could be negotiated within the existing framework of the international society based on sovereign States. It is hoped that through appropriate education of these guidelines, many States and self-determination movements can gain insight of a better way in terms of avoiding both human rights violation and armed conflicts. A framework for applying this principle would contribute to narrowing the gap between the romantic ideal of selfdetermination and its application on the ground for maximum benefit of people. 